Review

\title{
CURRENT KNOWLEDGE ON THE PATHOGENIC MECHANISMS OF HENOCH-SCHOENLEIN PURPURA IN CHILDREN
}

\author{
A.Vasileva $^{1^{*}}$, Iv. Chakarov ${ }^{2}$, P. Chakarova ${ }^{1}$ \\ ${ }^{1}$ Clinic of Pediatrics, UMHAT "Prof. Dr. Stoyan Kirkovich", Stara Zagora, Bulgaria \\ ${ }^{2}$ Clinic of Childhood Hematology and Oncology, UMHAT "Tsaritsa Yoanna-ISUL", \\ Sofia, Bulgaria
}

\begin{abstract}
The Schönlein-Henoch vasculitis is an IgA-mediated inflammation of small vessels. The main clinical manifestation is palpable purpura without thrombocytopenia, manifested by bilateral symmetrical distribution on both lower limbs, abdominal pain, often accompanied by blood in the stools, hematuria with / or without proteinuria.

Historically, the disease has been known since 1832. In Bulgaria, although that later HenochSchönlein purpura (HSP) aroused scientific interest, several publications focused on the pathogenic nature, clinical variations, and potential complications of the disease, as well as options for therapeutic intervention.

Modern knowledge about the etiology and pathogenesis of the disease has given new light, respectively a basis for early diagnosis, reduction of complications and recurrences, as well as the avoidance of polypragmatism.

It turned out that in HSP there are genetic factors and new aspects, binding until now accepted concept that there are no changes in the coagulation system. The role of factor XIII, as a prognostic indicator of the severity of clinical manifestations and von Willebrand factor (vWF), as a reliable index of the degree of vascular wall damage, has been demonstrated. Plasma imbalance in the Th1 / Th2 ratio was also found and a percentage of NK cells, respectively their immune function, were reduced.

This new knowledge about the pathogenic nature of HSP is the basis for a change in the concept of therapeutic behavior, which is aimed at the severity of the clinical course, and not only at the treatment of the disease, which is itself symptomatic.
\end{abstract}

Key words: Henoch-Schönlein purpura, Th1/Th2 imbalance, FcalphaRI, f.XIII, vWF

\section{INTRODUCTION}

The Henoch-Schonlein purpura is a vasculitis of the small vessels as a result of IgA-mediated inflammation. It is the most common acute systemic vasculitis in childhood, affecting mainly the skin, gastrointestinal tract, joints, and kidneys. The main clinical manifestation of HSP is purpura without thrombocytopenia, characterized by bilaterally symmetrically distributed palpable purpura on the both lower limbs, abdominal pain, arthralgia, blood in the stool, hematuria, and/or proteinuria. $(1,2)$

Increased production of polymeric IgA by the mucosal immune system in response to a

\footnotetext{
*Correspondence to: A.Vasileva, Clinic of Pediatrics, UMHAT "Prof. Dr. Stoyan Kirkovich", Stara Zagora, Bulgaria
}

mucosal antigen, such as bacteria, viruses, or fungi, is thought to be the major mechanism of HSP. In the acute phase of HSP, the concentrations of anti-inflammatory cytokines are increased, which causes endothelial damage. (3)

HSP is a disease of children between 3 and 10 years of age. The overall incidence in children is estimated at 3-26.7 cases per 100,000 $(4,5)$. Historically, the first description was made in 1832 from Schönlein in Berlin. Forty years later, Edward Henoch (6) described the association of gastrointestinal symptoms and a rash. There is an excellent description of Haberden in 1801 and another one from Wilan-1808. (7, 8) At the turn of the 19th century, William Osler devoted many of his active years to the study of the disease and 
VASILEVA A., et al.

developed the concept that it was anaphylactoid purpura. (8) In 1947 Douglas Gairdner wrote a book about the HSP.

Although Schönlein and Henoch gave their names to the disease, other notable physicians had noticed it, even earlier. In Bulgaria, the interest of pediatricians in HSP is associated with several scientific reports. St. Dimitrov (9) makes the first generalized description of Schönlein-Henoch disease. The first monographic work was published in 1966 by Lilyana Basheva-Staneva. (10) She adopted the immune-allergic genesis of Schönlein-Henoch and concluded that it was hyperergic vasculitis, concluding that bleeding and clotting times were always normal.

The long-standing "wanderings" of Bulgarian authors still give them a reason to conclude that Schönlein-Henoch is an allergic disease. All this had led to the belief that the disease is nothing more complicated than the described above and therefore followed several decades in which there are no scientific reports on the problem.

In 1993 Iv. Marinovsky (11) published a comprehensive article on the acute surgical problem in children with HSP. In 1996 a scientific paper by G. D. Georgiev was published (12), in which he shared the practical approaches in the treatment of HSP.

HSP is usually diagnosed based on the clinical features: purpuric rash, colic-like abdominal pain, arthralgia, and hematuria. The American College of Rheumatology describes the criteria for diagnosing HSP. (13) According to them and for this classification, a patient is considered to have HSP if at least two of the four criteria are present. The presence of two or more of them gives reliability in $87.1 \%$ and specificity in $87.7 \%$. (13)

Table 1. Criteria for HSP

\begin{tabular}{|c|l|}
\hline 1. Palpable purpura & $\begin{array}{l}\text { Slightly raised palpable hemorrhagic skin } \\
\text { lesions, non-thrombocytopenic }\end{array}$ \\
\hline 2. $\begin{array}{l}\text { Age over 3 years. at the initial } \\
\text { manifestation of the disease }\end{array}$ & $\begin{array}{l}\text { Age over 3 years at the initial manifestation of } \\
\text { the disease }\end{array}$ \\
\hline 3. Bowel angina & $\begin{array}{l}\text { Diffuse abdominal pain exacerbated by food, } \\
\text { infection, or diagnosis of intestinal ischemia, } \\
\text { usually involving bloody diarrhea }\end{array}$ \\
\hline 4. $\begin{array}{l}\text { Presence of granulocyte deposition in } \\
\text { the walls of arterioles and venules on } \\
\text { biopsy }\end{array}$ & $\begin{array}{l}\text { Histological changes showing granulocytes in } \\
\text { the walls of arterioles and venules }\end{array}$ \\
\hline
\end{tabular}

HSP is a disease mediated by immune complexes. Vascular deposition of IgAdominant immune complexes typically induces endothelial cell damage through the inflammatory action of cytokines and the involvement of inflammatory cells. $(14,15)$ Abnormally glycosylated IgA1 aggregates into macromolecular complexes that activate the alternative complement pathway and attract inflammatory cells. (16) Secretory mucosal IgA (SIIgA) provides immune exclusion by binding to pathogens in a hydrophilic confirmation of a sheath that is repelled by mucosal surfaces. Besides, IgA can neutralize bacterial products, agglutinate microbes, and interfere with bacterial motility. (17) IgA1 has an elongated hinge region due to the insertion of two octapeptide repeats. They have 3 to 6 common O-glycan sites to which O-glycans can be attached during glycosylation. IgA can activate complement proteins, but cannot activate the classical complement pathway because it lacks a C1q binding site.

Besides, $\operatorname{IgA}$ can bind and activate multiple receptors, and one of them is the transfer receptor CD71, which is universally expressed as a transmembrane glycoprotein. Overexpression of this receptor in mesenchymal cells is thought to facilitate the deposition of IgA-containing immune complexes in the mesangium. (18)

The prototype $\operatorname{IgA} 1$ receptor FcalphaRI is presented as a transmembrane receptor of soluble myeloid cells (sCD89). It may form immune complexes with $\operatorname{IgA}$ and is thought to play a role in the progression of $\operatorname{IgA}$ nephropathy. (19) Monomeric IgA can bind to FcalphaRI, but not crosswise, eliciting an antiinflammatory response. Monovalent binding to IgA results in the formation of intracellular structures called inhibisomes. (20) This process is called inhibitory immunoreceptor 
VASILEVA A., et al.

tyrosine signaling (ITAMI) and leads to a decrease in the regulation of immune activation. $(21,22)$

In contrast, binding of $\operatorname{IgA}$ immune complexes to neutrophil FcalphaRI causes activation of ITAMI signaling. FcalphaRI cross-linking results in a variety of anti-inflammatory functions such as phagocytosis, ROS production, cytokine and chemokine release, antibody-dependent cellular cytotoxicity (ADCC), and extracellular trap release. (19, 23) The activation of FcalphaRI induces the release of the chemoattractant LTB-4, which leads to neutrophil migration. (24) As neutrophils and $\operatorname{IgA}$ are present in $\operatorname{IgA}$ vasculitis lesions, the interaction between $\operatorname{IgA}$ and FcalphaRI likely plays a role in the pathogenesis of IgA vasculitis.

IgAN is characterized by $\operatorname{IgA} 1$ autoantibodies, but the antigen to which $\operatorname{IgA} 1$ binds is unknown. In IgA vasculitis, anti-endothelial cell antibodies (AECAs) are thought to be associated with the disease. (25)

Microorganisms most likely have similar antigenic structures as human vessel walls. Infections with these microorganisms lead to the production of cross-reactive AECA. (26) Ig AECA from IgAV patients is most likely to induce endothelial cells to produce cytokines such as IL-8, thereby promoting the inflammatory environment and inducing neutrophil chemotaxis. (27, 28) IgAN is characterized by IgA1 autoantibodies, but the antigen to which IgA1 binds is unknown. In IgA vasculitis, anti-endothelial cell antibodies (AECAs) are thought to be associated with the disease. (25) Microorganisms most likely have similar antigenic structures as human vessel walls. Infections with these microorganisms lead to the production of cross-reactive AECA. (26) AECA from IgAV patients is most likely to induce endothelial cells to produce cytokines such as IL-8, thereby promoting the inflammatory environment and inducing neutrophil chemotaxis. $(27,28)$

\section{Genetic factors and their role in the pathogenesis of IgAV}

The incidence of IgAV varies between ethnic groups, being highest among Southeast Asians and lowest among Americans. (31) Although rare, familial IgAV aggregation has been reported. (32) When comparing genetic variants between healthy and IgAV patients, the greatest difference was found in HLA genes. Variants HLA-DRB * 01 and HLADRB1 * 11 are associated with IgAV, while HLA-DRB $1 * 07$ is negatively associated with IgAV. (33) HLA genes encode MHC molecules that are important for T-cell antigen presentation.

\section{Disorders of the coagulation system}

Factor XIII (fibrin-stabilizing factor) decreases significantly during the acute phase of HSP and is a prognostic indicator of the severity of clinical manifestations of HSP. $(36,37)$

\section{vWF-predictor of vascular damage}

The von Willebrand factor level can be used as a specific marker of vascular damage and HSP activity. It is a plasma glycoprotein synthesized by megakaryocytes (38) and endothelial cells (39) isolated from large and small veins, capillaries and arteries, the aorta, which mediates platelet adhesion to the subendothelium and platelet aggregation by binding to the injured vessel wall.

Accumulated data on elevated von Willebrand factor concentrations are considered a reliable index of vascular damage. The possible correlation of vWFAg with the size of the affected blood vessel is also discussed. $(40,41)$ The von Willebrand factor does not play the role of an acute phase reagent, but as a marker of vascular damage. Elevated vWFAg values reflect the increased amount of circulating endothelial factor due to vascular damage. Values return to normal when patients are in remission and remain above normal levels with continued symptoms. The evaluation of vWFAg and RiCoF can be accepted as reliable tests for monitoring disease activity.

The level of the von Willebrand factor depends on the disease activity and there is no relationship between factor XIII and clinical symptoms. (42) In a large study, factor XIII was shown to decrease only in severe clinical cases. (43) However, neither study evaluated both markers of inflammation and activated coagulation in patients with HSP. Levels of fibrinogen, D-dimers, and FDPs are significantly higher during the acute phase of the disease compared to controls. D-dimers and FDPs are more strongly associated with the overall clinical score of HSP than inflammatory markers such as the number of WBC, ANC, CRP. 
D-dimers and FDPs can allow the clinicians to evaluate not only the effectiveness of treatment but also relapses, especially in young children. They also play an important role as indicators of GI tract involvement during the acute phase of HSP.

3. Immune imbalance in HSP Due to the still existing ambiguities in the pathogenesis of HSP, it is important to examine both the immune parameters and the underlying mechanisms in children with HSP. An imbalance in the Th1 / Th2 ratio, over activity of Th2 cells, which can cause an increase in the synthesis and release of immunoglobulins, has been established. The percentage of NK cells is also reduced, as well as their immune function, which is associated with immune damage to the digestive tract and kidneys.

An established low level of IL-2 may reduce the immune function of NK cells. This affects the ability to remove foreign antigens and an increased risk of damage to the digestive and urinary systems. The increased number of Bcells is evidence that gastrointestinal involvement is associated with CD4 + and CD8 + imbalance.

\section{Perspectives in the therapeutic approach in HSP}

It is now generally accepted that HSP is a selflimiting disease. New knowledge on the pathogenic nature of HSP provides new directions and changes the current concept that HSP treatment is only supportive and symptomatic focused on controlling the severity of the clinical course, and not on its treatment itself.

Although newer drugs also require more research and experimentation, their expected effectiveness, based on new knowledge about the pathogenic mechanisms of HSP, motivates their use in the therapeutic plan in children with HSP.

\section{REFERENCES}

1. Trapani S, Micheli A, Grisolia F, Resti M, Chiappini E, Falcini F, et al. Henoch Schonlein purpura in childhood: epidemiological and clinical analysis of 150 cases over 5 years and review of the literature. Semin Arthritis Rheum; 35:14353; 2005.

2. Calviño MC, Llorca J, García-Porrúa C, Fernández-Iglesias JL, Rodriguez-Ledo $\mathrm{P}$,
VASILEVA A., et al.

González-Gay MA. Henoch-Schönlein purpura in children from northwestern Spain: a 20-year epidemiologic and clinical study. Medicine (Baltimore);80:279-90; 2001.

3. Mills JA, Michel BA, Bloch DA, Calabrese LH, Hunder GG, Arend WP, et al. The American College of Rheumatology 1990 criteria for the classification of HenochSchönlein purpura. Arthritis Rheum 33:1114-21; 1990.

4. Piram M, Mahr A. Epidemiology of immunoglobulin A vasculitis (HenochSchönlein): current state of knowledge. Curr Opin Rheumatol; 25:171-8; 2013.

5. Roberts PF, Waller TA, Brinker TM, Riffe IZ, Sayre JW, Bratton RL, HenochSchönlein purpura: a review article. South Med J; 100:821-4; 2007.

6. Henoch, E (1868). Verhandlungen arztlicher Gesellschaffen. Berliner klinische Wohenschrift, 5, 517.

7. Heberden, W. (1801) Commentarii di Morborium-Historia et Curatione, chapter 78. Payne: London.

8. Willan, R. (1808). On Cutaneous Disease. Johnson: London.

9. Dimitrov St., Bulgarian clinic; 8, 614-617; 1948.

10.L. Basheva-Staneva, The illness of Schonlein-Henoch, 1996

11.Iv. Marinovsky, M. Mikhova, H. Hristov, A. Apostolova. Acute Abdomen in Schonlein-Henoch Disease in Childhood, Emergency medicine, 1:11-13; 1993.

12. Г. Д. Георгиев, Практически подходи при лечение на болестта на ШонлайнХенох, 1996.

13.Bailey M, Chapin W, Licht $\mathrm{H}$, et al. The effects of vasculitis on the gastrointestinal tract and liver. Gastroenterol Clin North Am; 27: 747-782; 1998.

14. Faille-Kuyber EH, Kater L, Kooiker CJ, Dorhout Mees EG. IgA-deposits in cutaneous blood-vessel walls and mesangium in Henoch-Schönlein syndrome. Lancet; 1:892-3; 1973.

15.Besbas N, Saatci U, Ruacan S, Ozen S, Sungur A, Bakkaloglu A, et al. The role of cytokines in Henoch Schönlein purpura. Scand J Rheumatol; 26: 456-60; 1997.

16. Yang YH, Chuang YH, Wang LC, Huang HY, Gershwin ME, Chiang BL. The immunobiology of Henoch- Schonlein purpura. Autoimmun Rev; 7:179-84; 2008.

17. Aleyd E, Heineke MH, van Egmond M. The era of the immunoglobulin $\mathrm{A} \mathrm{Fc}$ 
receptor FcalphaRI; its function and potential as a target in disease. Immunol Rev; 268: 123-38; 2015.

18. Moura IC, Centelles MN, Arcos-Fajardo M, Malheiros DM, Collawn JF, Cooper MD, et al. Identification of the transferrin receptor as a novel immunoglobulin (Ig) A1 receptor and its enhanced expression on mesangial cells in IgA nephropathy. J Exp Med; 194: 417-25; 2001.

19.van Zandbergen G, Wasterhuis R, Mohamad NK, van De Winkel JG, Daha MR, van Kooten C. Crosslinking of the human $\mathrm{Fc}$ receptor for IgA(FcalphaRI/CD89) triggers FcR gamma-chain-dependent shedding of soluble CD89. J Imminol; 163: 5806-12; 1999.

20.Blank U, Launay P, Benhamou M, Monteiro RC. Inhibitory ITAMs as novel regulators of immunity. Immunol Rev; 232: 59-71; 2009.

21.Pasquier B, Launay P, Kanamaru Y, Moura IC, Pfirsch S, Ruffie C, et al. Identification of FcalphaRI as an inhibitory receptor that controls inflammation: dual role of FcR gamma ITAM. Immunity; 22: 31-42; 2005.

22.Ben Mkaddem S, Rossato E, Heming N, Monteiro RC. Anti-inflammatory role of the $\operatorname{IgA} \mathrm{Fc}$ receptor (CD89): from autoimmunity to therapeutic perspectives. Autoimmun Rev; 12: 666-9; 2013.

23. Heineke $M$, van Egmond $M$. Immunoglobulin A: magic bullet or Trojan horse? Eur J Clin Investig 2016.

24.van der Steen L, Tuk CW, Bakema JE, Kooij G, Reijerkerk A, Vidarsson G, et al. Immunoglobulin A: $\mathrm{Fc}($ alpha)RI interactions induce neutrophil migration through release of leukotriene B4. Gastroenterology; 137: 2018-29; 2009.

25.Legendre $P$, Regent A, Thiebault M, Mouthon L. Anti-endothelial cell antibodies in vasculitis: a systematic review. Autoimmun Rev; 28: 794-7; 2017.

26. Yang Y-H, Wang SJ, Chiang Y-H, Lin YT, Chiang B-L. The level of IgA antibodies to human umbilical vein endothelial cells can be enhanced by TNF- $\alpha$ treatment in children with Henoch-Schönlein purpura. Clin Exp Immunol; 130: 352-7; 2002.

27.Yang YH, Lai HJ, Huang CM, Wang LC, Lin Yt, Chiang BL. Sera from children with active Henoch-Schönlein purpura can enhance the production of interleukin 8 by human umbilical venous endothelial cells. Ann Rheum Dis; 63: 1511-3; 2004.
VASILEVA A., et al.

28. Yang Y-H, Huang Y-H, Lin Y-L, Wang L$\mathrm{C}$, Chuang Y-H, Yu H-H, et al. Circulating IgA from acute stage of childhood HenochSchönlein purpura can enhance endothelial interleukin (IL)-8 production through MEK/ERK signaling pathway. Clin Exp Immunol; 144: 247-53; 2006.

29.Davin JC, Ten Berge IJ, Weening JJ. What is the difference between $\operatorname{IgA}$ nephropathy and Henoch-Schönlein purpura nephritis? Kidney Int; 59: 823-34; 2001.

30. Yang Y-H, Tsai I-J, Chang C-J, Chuang Y$\mathrm{H}$, Hsu H-Y, Chiang B-L. The interaction between circulating complement proteins and cutaneous microvascular endothelial cells in the development of childhood Henoch-Schönlein purpura. PLoS One; 10: e0120411; 2015.

31.Lau KK, Suzuki H, Novak J, Wyatt RJ. Pathogenesis of Henoch-Schönlein purpura nephritis. Pediatr Nephrol 2010; 25: 19-26; 2015.

32.Ostini A, Simonetti GD, Pellanda G, Bianchetti MG, Ferrarini A, Milani GP. Familial Henoch-Schönlein syndrome. $J$ Clin Rheumatol; 22: 80-1; 2016.

33.He X, Yu C, Zhao P, Ding Y, Liang X, Zhao $Y$, et al. The genetics of HenochSchönlein purpura: a systematic review and meta-analysis. Rheumatol Int; 33: 1387-95; 2013.

34.Levi M, van der Poll T. Two-way interactions between inflammation and coagulation. Trends Cardiovase Med; 15: 254-9; 2005.

35.Szaba FM, Smiley ST. Roles for thrombin and fibrin(ogen) in cytokine/chemokine production and macrophage adhesion in vivo. Blood; 99: 1053-9; 2002.

36. Dalens B, Travade P, Labbè A, Bezou MJ. Diagnostic and prognostic value of fibrin stabilising factor in Schönlein-Henoch syndrome. Arc Dis Child; 58: 12-4; 1983.

37.Kamitsuji H, Tani K, Yasui M, Taniguchi A, Taira K, Tsukada S, et al. Activity of blood coagulation factor XIII as a prognostic indicator in patients with Henoch-Schönlein purpura. Efficacy of factor XIII substitution. Eur J Pediatr; 146: 519-23; 1987.

38.Sporn LA, Chavin SI, Marder VJ, Wagner DD. Biosynthesis of von Willebrand protein by human megakaryocytes. $J$ Clin Invest; 76: 1102-6; 1985.

39.Jaffe EA, Hoyer LW, Nachman RL. Sythesis of von Willebrand factor by 
cultured human endothelial cells. Proc Natl Acad Sci USA; 71: 1906-9; 1974.

40.Nusinow SR, Federici AB, Zimmerman TS, Curd JG. Increased von Willebrand factor antgen in the plasma of patients with vasculitis. Arthritis Rheum; 27: 1405-10; 1984.

41.Woolf AD, Wakerley G, Wallington TB, Scott DGI, Dieppe PA. Factor VIII related antigen in the assessment of vasculitis. Ann Rheum Dis; 46: 441-7; 1987.

42.De Mattia D, Penza R, Giordano P, Del Vacchio GC, Aceto G, Altomare M, et al. von Willebrand factor and factor XIII in children with Henoch-Schönlein purpura. Pediatr Nephrol; 9: 603-5; 1995.

43.Brandel-Müller K, Hahn A, Schneppenheim R, Santer R. Laboratory signs of activated coagulation are common in Henoch-Shcönlein purpura. Pediatr Nephrol; 16: 1084-8; 2001. 